كمىسازى سبز شدن بذر كوشيا (Kochia indica) تحت تأثير دما، شورى و عمق كاشت

\author{
غلامحسن رنجبر "،"، حسين غديرى ' \\ 'استاديار مركز ملى تحقيقات شورى، سازمان تحقيقات، آموزش و ترويج كشاورزى، يزد

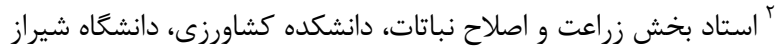

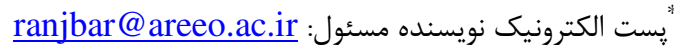

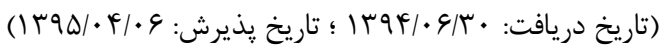

جكيده

جهت كمىسازى ميزان سبز شدن كوشيا (Kochia indica) تحت سطوح مختلف دما، شورى و عمق كاشت،

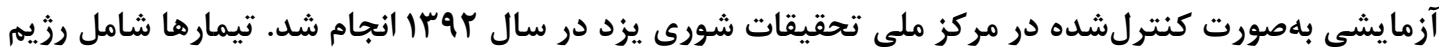

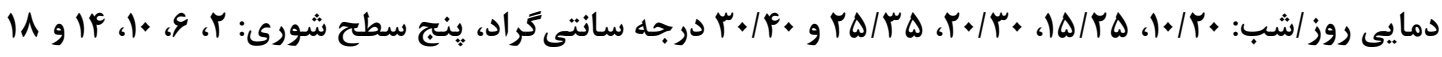

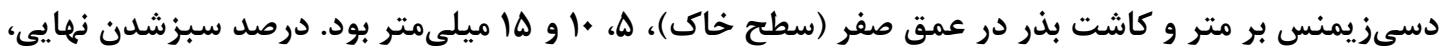

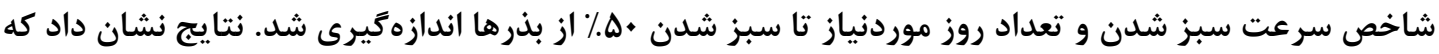

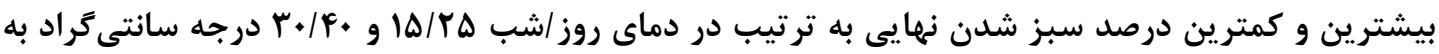

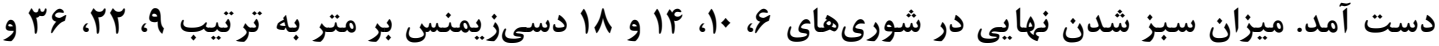

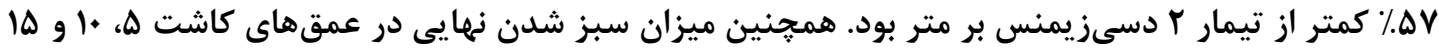

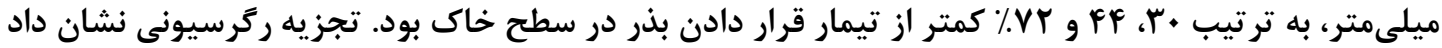

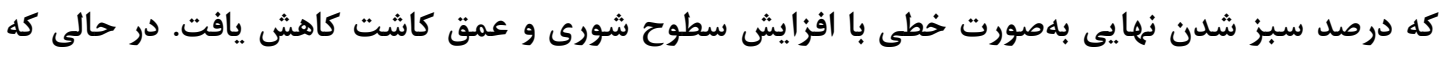

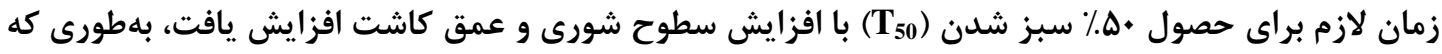

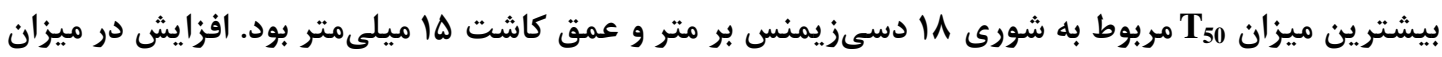

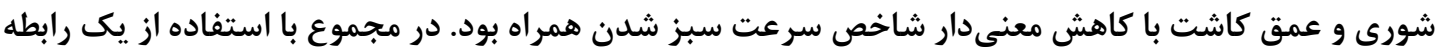
ركرسيونى لجستيك، ميزان سبز شدن بذر K. indica در هر روز يس از كاشت در تركيبات مختلف شورى و

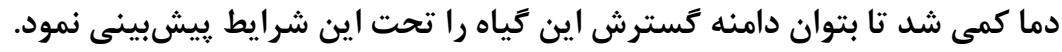

وازههاى كليدى: ركرسيون خطى، شاخص سرعت سبز شدن، علف هرز، عمق كاشت، رابطه لجستيك

كشاورزى خسارت وارد مى كنند (ليبمن' و همكاران،

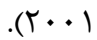

سبز شدن بذر يك مرحله حساس در زندگى كياه

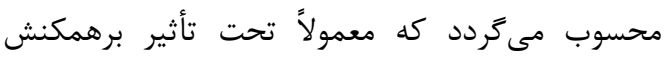

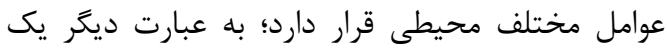

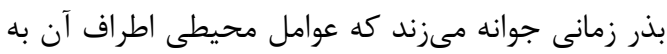

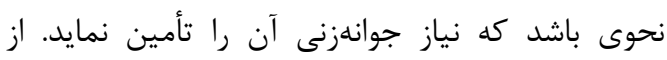

مقدمه

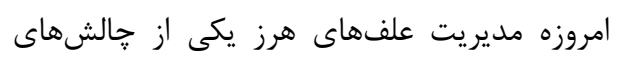

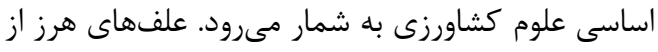

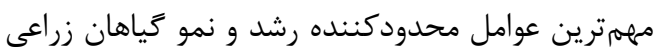
مىباشند و موجب كاهش عملكرد و كيفيت محصولات

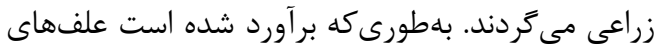

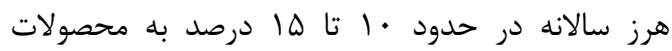

\footnotetext{
${ }^{1}$ Liebman
} 


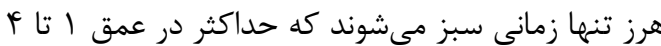

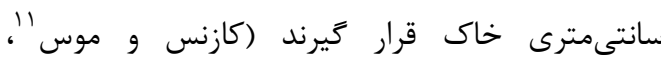
. (199.

تنش شورى يكى ديخر از عوامل محيطى است كه رشد كياه را در تمام مراحل نمويى تحت تأثير قرار مىدهد، اكرجه ميزان تحمل به شورى در در مراحل

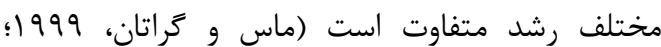

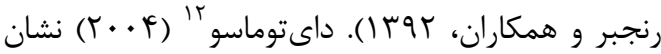
داد كه جوانهزنى Ambrosia artemisiifolia

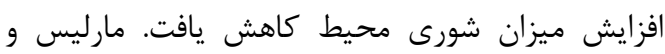

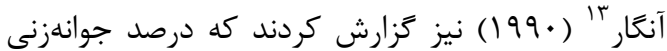
در دزكال (Echinochloa crus-galli) با افزايش غلظت كلريد سديم كاهش يافت. با اين حال كيانتُ

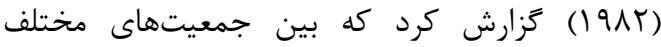
Anthoxantum odoratum از نظر تحمل به شورى در مرحله جوانهزنى و سبز شدن تفاوت وجود دارد. نتايج

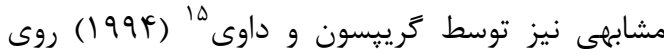
جمعيتهاى Leymus arenarius كَارش شده است. كونههاى مختلف كوشيا با توجه به تحمل به شورى نسبتاً بالاى آنها مدتهاست كه در كشور از نظر توليد علوفه كمكى در شرايط شور موردتوجه قرار كرفتهاند

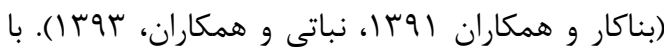
توجه به يتانسيل تهاجمى كوشيا در سيستمهاى زراعى،

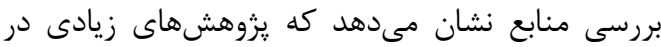

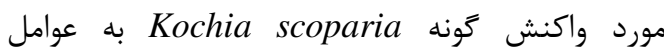

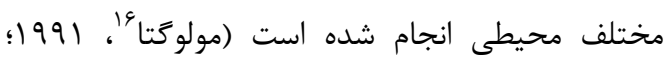

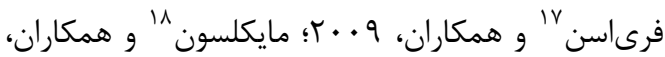

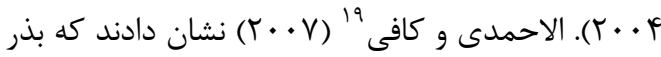
اين كونه در شرايط تاريكى در دامنه دمايى بين ه تا •ه

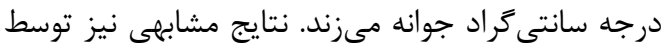

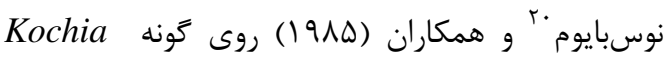

\footnotetext{
${ }^{11}$ Cousens and Moss

${ }^{12}$ DiTommaso

${ }^{13}$ Marlis and Ungar

${ }^{14}$ Kiang

${ }^{15}$ Greipsson and Davy

${ }^{16}$ Mulugeta

${ }^{17}$ Friesen

${ }^{18}$ Mickelson

${ }^{19}$ Al-Ahmadi and Kafi

${ }^{20}$ Nussbaum
}

مههمترين اين عوامل مىتوان به دماى محيط (ينفيلد'،

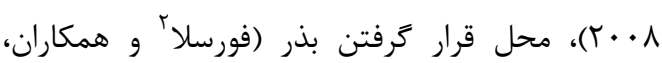

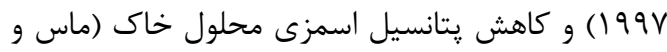

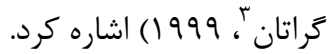
شايد بتوان كفت كه دما مهمترين عامل محيطى

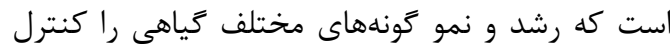

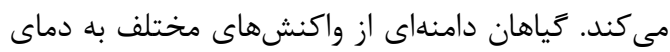
محيط از خود نشان مى دهند. بسته به گونه و مرحله

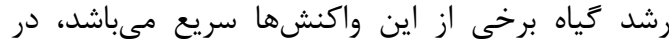
حالى كه برخى ياسخهاى گَياه به دما مثل شكسته شدن

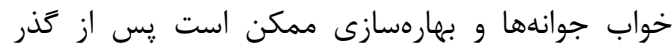

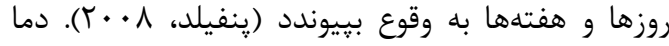
همجنين در سبز شدن كياه يك عامل محيطى مهائم

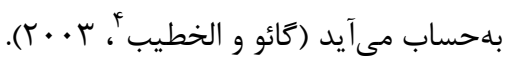

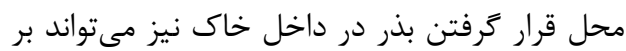
جوانهزدن و سبز شدن آن تأثير بحذارد. بر اساس يك داء قاعده كلى درصد سبز شدن با افزايش عمق كاشت آند

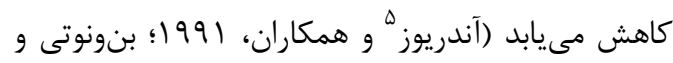

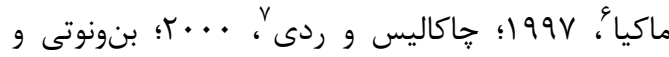

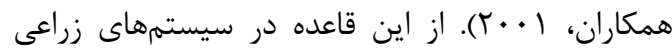

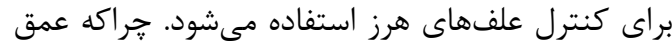

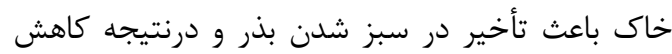

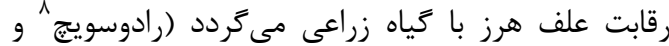

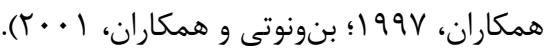

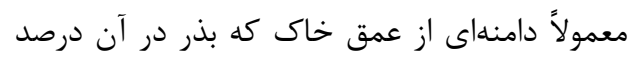
سبز شدن موفقى خواهد داشت، به عوامل عمدهاى از

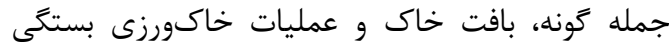

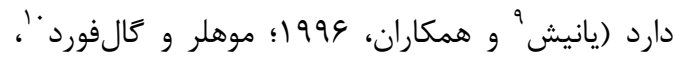
199V (19). با اين حال علىرغم تنوع وسيع بين كياهان زراعى از نظر دامنهاى از عمق خاك كه بذر آنها مىتواند سبز شود، بذر اغلب كياهان بلويزه علفهاى آناى

\footnotetext{
${ }^{1}$ Penfield

${ }^{2}$ Forcella

${ }^{3}$ Maas and Grattan

${ }^{4}$ Guo and Al-Khatib

${ }^{5}$ Andrews

${ }^{6}$ Benvenuti and Macchia

${ }^{7}$ Chachalis and Reddy

${ }^{8}$ Radosevich

${ }^{9}$ Yenish

${ }^{10}$ Mohler and Galford
} 
شامل ينج رزيم دمايى روز/شب شامل • •/T/·،

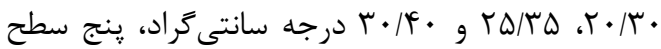

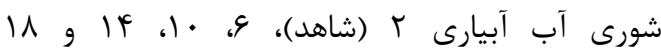

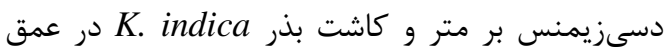
صفر (سطح خاك)، ه، · ا و ها ميلىمتر زير خاك بود. شورى آب آبيارى با رقيق كردن آب خاه طبيعى موجود

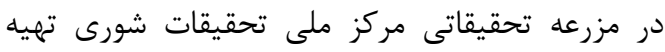

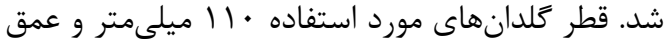

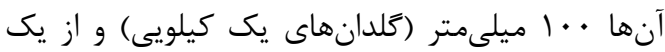

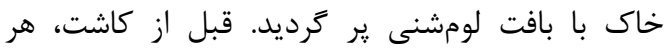
كلدان بلهوسيله شورى موردنظر بهاندازهاى كه آب به به به

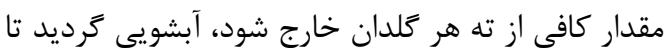

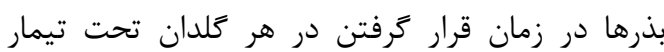

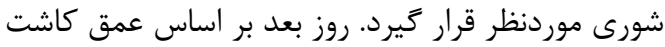

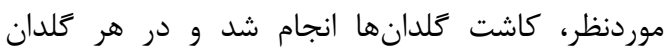

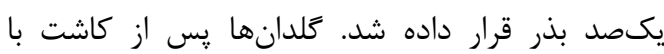
تيمارهاى آبشور موردنظر آبيارى شدند. جهت ممانعت

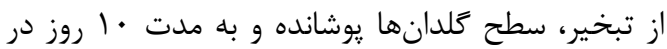

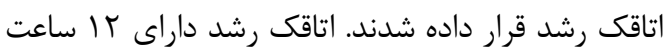
روشنايى به ميزان

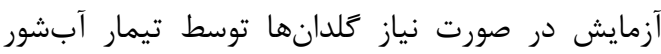

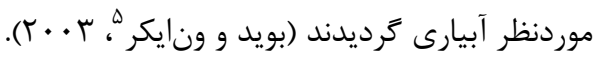
بازديد از كلدانها هر روز انجام شد و وردئن روزانه تعداد بذر سبز شده شمارش كرديد. درصد بذرهاى سبز شده

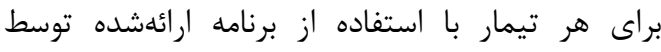

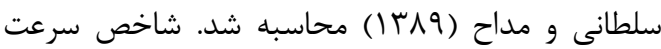

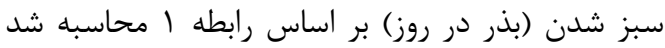

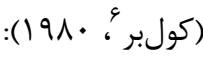

$$
\text { ERI }=\sum\left(\frac{N_{i}}{i}\right) \quad \text { 1ابطه }
$$

در اين رابطه، Ne تعداد بذر سبز شده در روز i

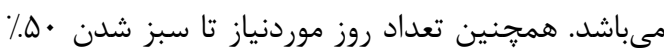

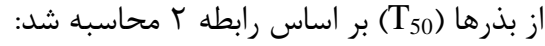
رابطه r:

$$
T_{50}=t_{i}+\left[\left(t_{j}-t_{i}\right) \times\left(\frac{\frac{N}{2}-n_{i}}{n_{j}-n_{i}}\right)\right]
$$

\footnotetext{
${ }^{5}$ Boyd and Van Acker

${ }^{6}$ Coolbear
}

scoparia جوانهزنى تحمل زيادى به شورى، تنش آب و شرايط

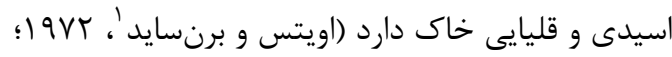

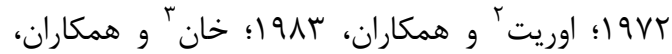

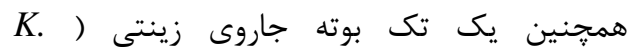

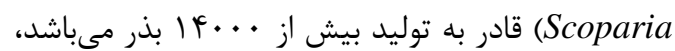

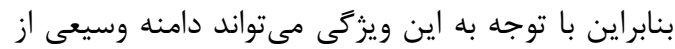

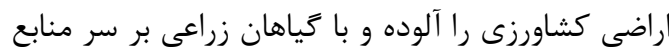

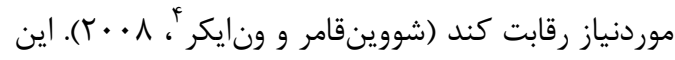
اين اطلاعات مىتواند در مديريت اين كونه در كنار

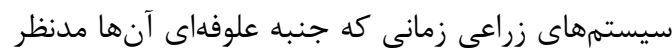
باشد، مفيد واقع كردد. كونه ديكر كوشيا،

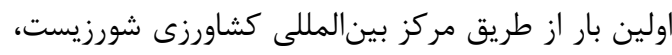

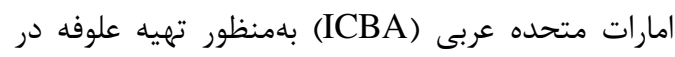
شرايط شور مناطق مركزى وارد كشور شد. علىرغم توليد بالاى ماده خشك اين كونه در شرايط شور (بناكار

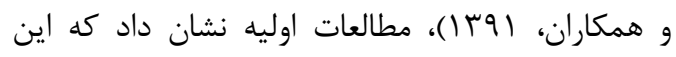

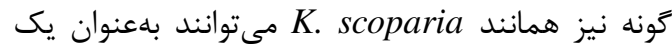

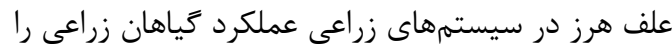

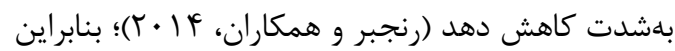

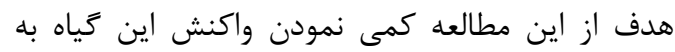

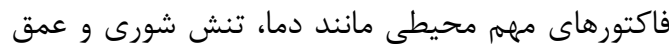

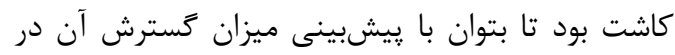
مناطقى كه توليد علوفه آن مدنظر است، راهكارهاى

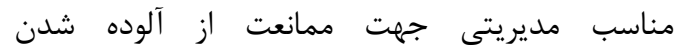
سيستمهاى زراعى توسط اين گَونه به كاربرده شود.

مواد و روشها بلمنظور كمىسازى تأثير عوامل مختلف محيطى بر ميزان سبز شدن بذر Kochia indica يك مطالعه كلدانى در اتاقك رشد آزمايشعاه مركز ملى تحقي تحقيقات

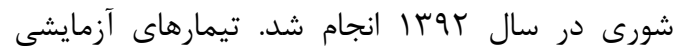

\footnotetext{
${ }^{1}$ Evetts and Burnside

${ }^{2}$ Everitt

${ }^{3}$ Khan

${ }^{4}$ Schwinghamer and Van Acker
} 


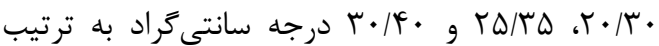

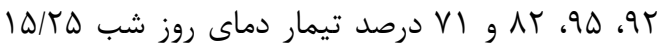
درجه سانتى گراد بود. بطوركلى نتايج اين آزمايش نشان

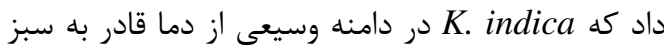
شدن مىباشد. نتايج مشابهى توسط درخشان و همكاران

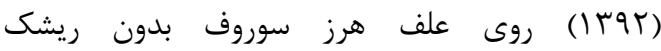
Echinochloa colonum

$$
\text { آزمايش حاضر ززارش شده است. }
$$

بيشترين شاخص سرعت سبز شدن در تيمار دمايى

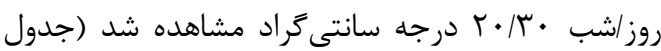
(). دماهاى بيشتر و كمتر از دماى روز/شب • •r/ درجه سانتى كاهش داد. در واقع شاخص سرعت سبز شدن بيانگر

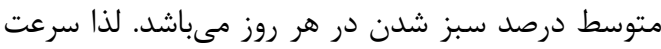
سبز شدن بالا نشاندهنده مدت زمان كمتر براى سبز

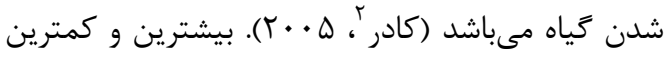
مدت زمان لازم جهت حصول به •ه. بذر بـ سبز شده $\left(T_{50}\right)$

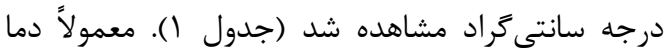
باعث افزايش درصد سبز شدن تا يك حد بـ بيشينه مى گردد و يس از اين نقطه هم درصد سبز شدن و هم

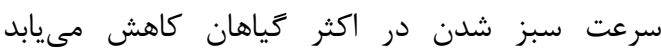

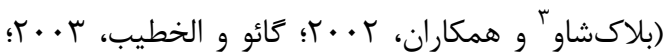

$$
\text { شوينقامر و ونايكر، } 9 \text { + . (؟). }
$$

جدول ا- درصد سبز شدن نهايى (FE)، شاخص سرعت سبز

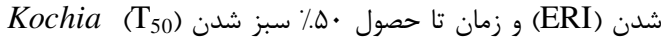

\begin{tabular}{|c|c|c|c|}
\hline $\begin{array}{l}\mathrm{T}_{50} \\
(j g)\end{array}$ & $\begin{array}{c}\text { ERI } \\
\text { (بذر در روز) }\end{array}$ & $\begin{array}{c}\text { FE } \\
(د, ص د)\end{array}$ & (روز/شب دما C) \\
\hline F/T & $19 / 94$ & $\Delta 1 / T V$ & $1 \cdot / r$. \\
\hline$r / \mathcal{A} \Delta$ & 19/Dr & $\Delta \Delta / \zeta$. & $\mid \Delta / T \Delta$ \\
\hline سז/ץ & TV/VD & $\Delta K / \Delta V$ & $r \cdot \pi \cdot$ \\
\hline$r / q F$ & TF/FT & 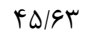 & $r \Delta / r \Delta$ \\
\hline$r / V \Delta$ & $I V / F F$ & r & $r \cdot / \boldsymbol{c}$. \\
\hline$\cdot \pi$. & $1 / 94$ & $r / 99$ & LSD \\
\hline
\end{tabular}
indica

${ }^{2}$ Kader

${ }^{3}$ Blackshaw
در اين رابطه $n_{i} n_{j}$ به ترتيب تعداد تجمعى بذر سبز شده بين دو روز

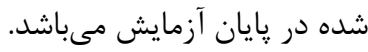
ويزگى هاى اندازهزيرى شده در برنامه استفاده از رويه PROC GLM تجزيه واريانس شد. مقايسه ميانگينها نيز با استفاده از آزمون حداقل تفاوت معنى دار و در سطح احتمال ه.٪ انجام شد. علاوه تجزيه رگرسيونى فاكتورهاى معنىدار شده، براى محاسبه درصد سبز شدن گياه بلصورت روزانه، ميزان تجمعى

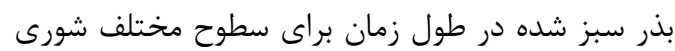
و در هر رزيم دمايى با استفاده از مدل لجستيكى تورنلى

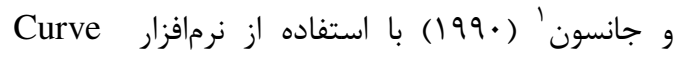
Expert 1.3

$Y=\frac{a}{\left(1+\exp \left[-\frac{(x-c)}{b}\right]\right)}$

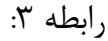

در اين رابطه a كل بذر سبز شده، c نشاندهنده تعداد روز موردنياز براى حصول حداكثر سرعت سبز شدن و بيان كننده تعداد روزى است كه سبز شدن اتفاق افتاده است و x زمان مىباشد.

براى تعيين رابطه بين متغيرهاى شورى و وعمق كاشت با درصد سبز شدن نهايى، شاخص سرعت سبز شدن و T50، از تجزيه ركرسيونى جند

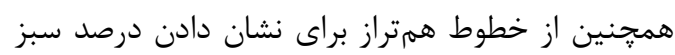
نهايى، شاخص سرعت سبز شدن و T50 در واكنش به ميزان هاى مختلف شورى و عمق كاشت استفاده شد.

نتايج و بحث

اثر دما

بيشترين درصد سبز شدن Kochia indica در دماى روز/شب ه/ D/T درجه سانتى اگرجه تعداد كل بذر سبز شده در در دماهاى روز/شب

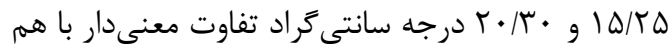
نداشتند (جدول ()). كمترين ميزان درصد سبز شدن نيز

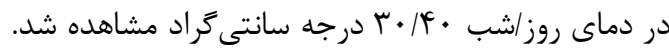
تعداد كل بذر سبز شده در دماهاى روز/شب • ז/• ا،

\footnotetext{
${ }^{1}$ Thornley and Johnson
} 


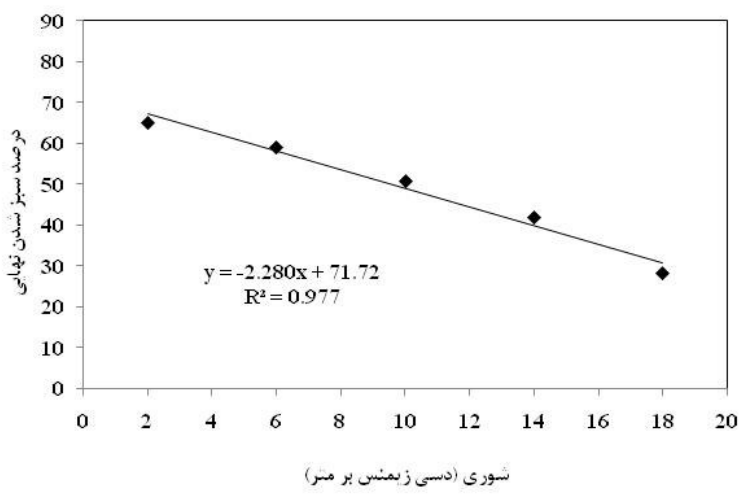

شكل ا- كمىسازى واكنش سرعت سبز شدن كوشيا به سطوح

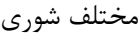

برهمكنش شورى و رزيم دمايى بر درصد سبز شدن K. indica افزايش ميزان شورى باعث كاهش درصد سبز شدن بذر در هر سطح رزيم دمايى گرديد، بهطورى كه در هر تيمار دمايى كمترين تعداد نهايى بذر سبز شده در شورى آب 1| دسىزيمنس بر متر مشاهده شد. در اين

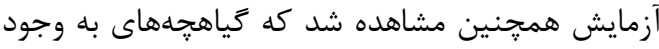

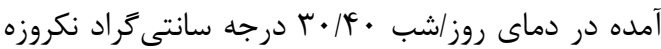
و صدمه ديده بودند كه احتمالاً به خاطر قرار گرفتن در رور

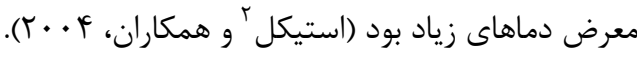
بيشترين و كمترين شاخص سرعت سبز شدن در هر رزيم دمايى به ترتيب مربوط به شورى ب و 11 دسىزيمنس بر متر بود (شكل r-ب). ميزان شاخص

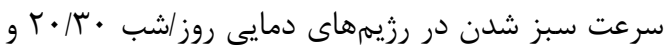

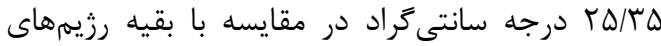

$$
\text { دمايى بيشتر بود. }
$$

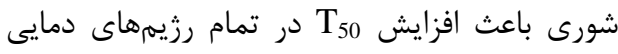

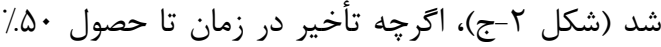
سبز شدن توسط شورى در تيمار دمايى روز/شب • T/ •

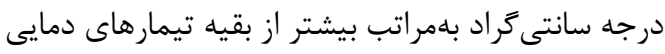

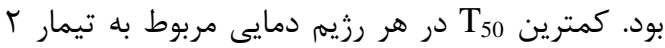

$$
\text { دسىزيمنس بر متر بود. }
$$

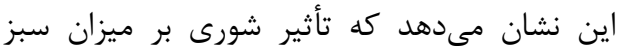

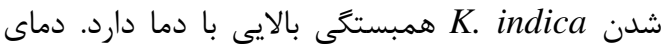

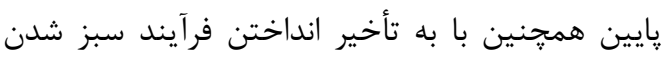

\footnotetext{
${ }^{2}$ Steckel
}

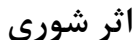

تنش شورى بلهطور معنى

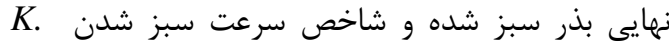
indica

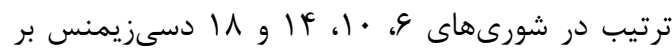

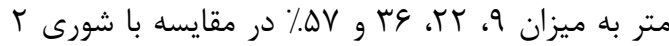
دسىزيمنس بر متر (شاهد) كاهش يافت. در عوض شورى باعث افزايش T50 شد، بهطورى كه حداكثر T50 در تيمار شورى \| دسىزيمنس بر متر به دست آمد

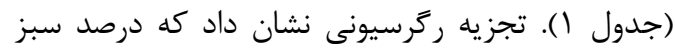

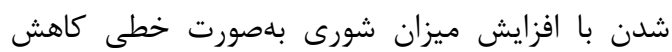

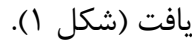
مرحله سبز شدن گياه يك مرحله بحرانى در شرايط شور محسوب مى و گراتان، 999 (1)، بنابراين استقرار مناسب بوته در اين مرحله مىتواند به بهبود عملكرد در شرايط شور بيانجامد. به دليل اينكه آب توسط نيروى اسمزى در بر برد محلول خاك قرار دارد، غلظت بالاى نمك مىتواند در جذب آب توسط بذر و فرآيند جوانهزنى اختلال ايجاد

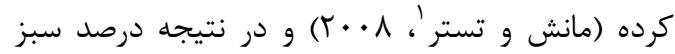
شدن را كاهش دهد. كاهش در ميزان سبز شدن بذر علفهاى هرز در شرايط شور بلوسيله ديخران نيز

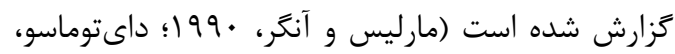

.$(r \cdot r$

جدول r- درصد سبز شدن نهايى (FE)، شاخص سرعت سبز

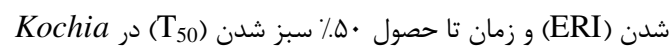

\begin{tabular}{|c|c|c|c|}
\hline $\begin{array}{l}\mathrm{T}_{50} \\
\text { (روز) }\end{array}$ & $\begin{array}{c}\text { ERI } \\
\text { (بذر در روز) }\end{array}$ & $\begin{array}{c}\text { FE } \\
(د, د)\end{array}$ & $\begin{array}{c}\text { شورى } \\
(\mathrm{dS} / \mathrm{m})\end{array}$ \\
\hline$r / 9 \mid$ & $41 / 19$ & $\varphi \Delta / \cdot 9$ & r \\
\hline$r / \Lambda \Lambda$ & TV/TG & $\Delta \wedge / 9 \Delta$ & 9 \\
\hline$r / T F$ & Tr/VG & $\Delta \cdot / V I$ & 1. \\
\hline$r / 9 \Delta$ & IV/TV & $f \mid / v \wedge$ & If \\
\hline$r / r q$ & $1 . / 19$ & $r \Lambda / \cdot G$ & 11 \\
\hline$\cdot / r$. & $1 / 94$ & $r / 99$ & LSD \\
\hline
\end{tabular}
indica

\footnotetext{
${ }^{1}$ Munns and Tester
} 


\section{رنجبر و غديرى: كمىسازى سبز شدن بذر كوشيا تحت تأثير دما، شورى و عمق كاشت}

خاك به دست آمد. ميزان شاخص سرعت سبز شدن به

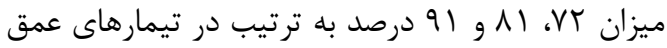

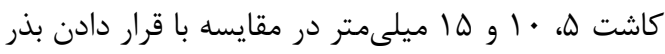
در سطح خاى كاهش يافت. نتايج مشابهى توسط سلطانى و همكاران، (19 (1) روى بذر كلزاى خودرو و خردل وحشى و گروندى

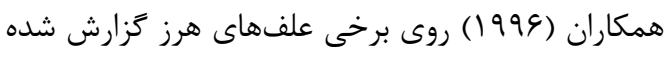

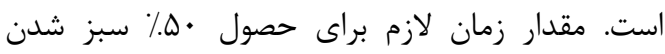
(T) $\left(T_{50}\right)$

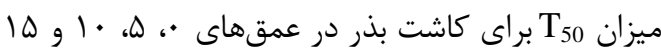
ميلىمتر به ترتيب س/ r، آ و و T/9 برابر بيشتر از قرار دادن بذر در سطح خاك (صفر ميلىمتر) بود.

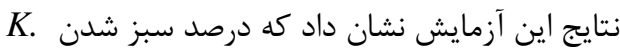
همانند K. scoparia indica

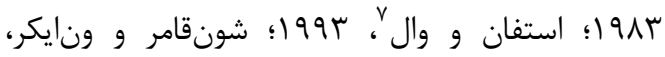
9 + . †) در سطح خاك بيشترين ميزان بود و با افزايش عمق كاشت كاهش جشمخًير نشان داد.

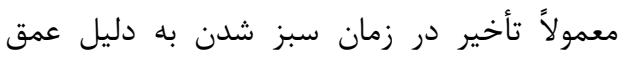
بيشتر خاك بدين مفهوم است كه علف هرز پس از گياه زراعى سبز خواهد شد و رقابتيذيرى آن در مقايسه با

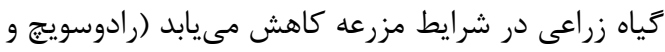

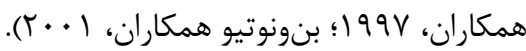
تخليه گَلدانها پس از آزمايش نشان داد كه اخرجه بذرهاى قرار گرفته در عمقهاى بيشتر خاى جوانهزده ولى در مدت زمان اين آزمايش قادر به خروج از سطح

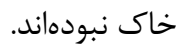
بنابراين كاهش درصد سبز شدن نهايى در تيمارهاى با عمق بيشتر، به خاطر كاهش در شاخص سرعت سبز

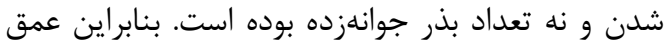
بيشتر كاشت باعث تحريك خواب در بذر گياه نشده
${ }^{6}$ Grundy

${ }^{7}$ Stepphun and Wall
باعث مىشود بذرهاى جوانهزده شده تحت تأثير تنشهاى ديگرى مانند سله خاى و بيمارىهاى قارجى قرار بخيرند كه مىتواند بهطور مضاعف تعداد بوته سبز

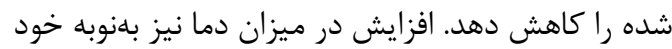
مىتواند به افزايش تبخير از سطح خاك، كاهش

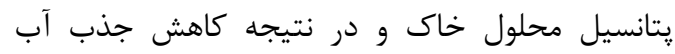

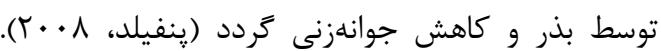

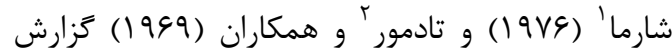
كردند كه اثر منفى كاهش ڤتانسيل آب بر جوانهزنى زمانى كه دما در حالت مطلوب قرار ندارد بسيار شديدتر مىباشد؛ بنابراين براى انجام فرآيند جوانهزنى و سبز

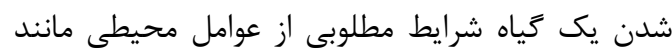

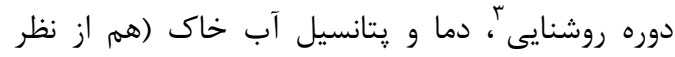

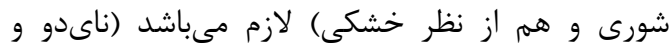

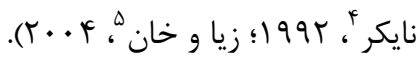

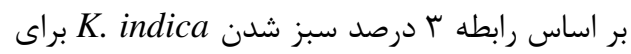
هر تركيب دمايى و تيمار شورى كمى شد (جدول س). با رل

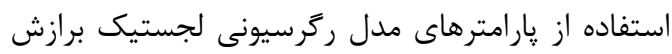
شده، مىتوان ميزان سبز شدن اين گياه بهصورت روزانه را براى هر تركيب شورى-دمايى با ضريب تبيين بيشتر از

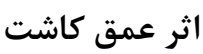
نتايج نشان داد كه بدون توجه به دما و شورى، J مرد سبز شدن نهايى و شاخص سرعت سبز شدن indica

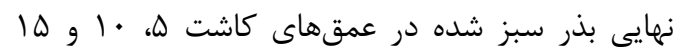
ميلىمتر در مقايسه با قرار دادن بذر در سطح خاى به به

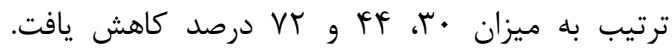

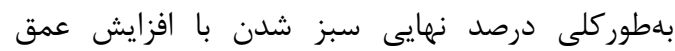
بهصورت خطى كاهش يافت (شكل ب)؛ به عبارت ديخر كاشت بذر در عمق بيشتر به تأخير بيشتر در زمان سبز

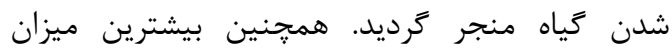
شاخص سرعت سبز شدن با قرار دادن بذر در سطح

\footnotetext{
${ }^{1}$ Sharma

2 Tadmore

${ }^{3}$ Photoperiod

${ }^{4}$ Naidoo and Naicker

${ }^{5}$ Zia and Khan
} 
مجله يثوهشهاى بذر ايران / سال سوم/ شماره دوم/ هوسا
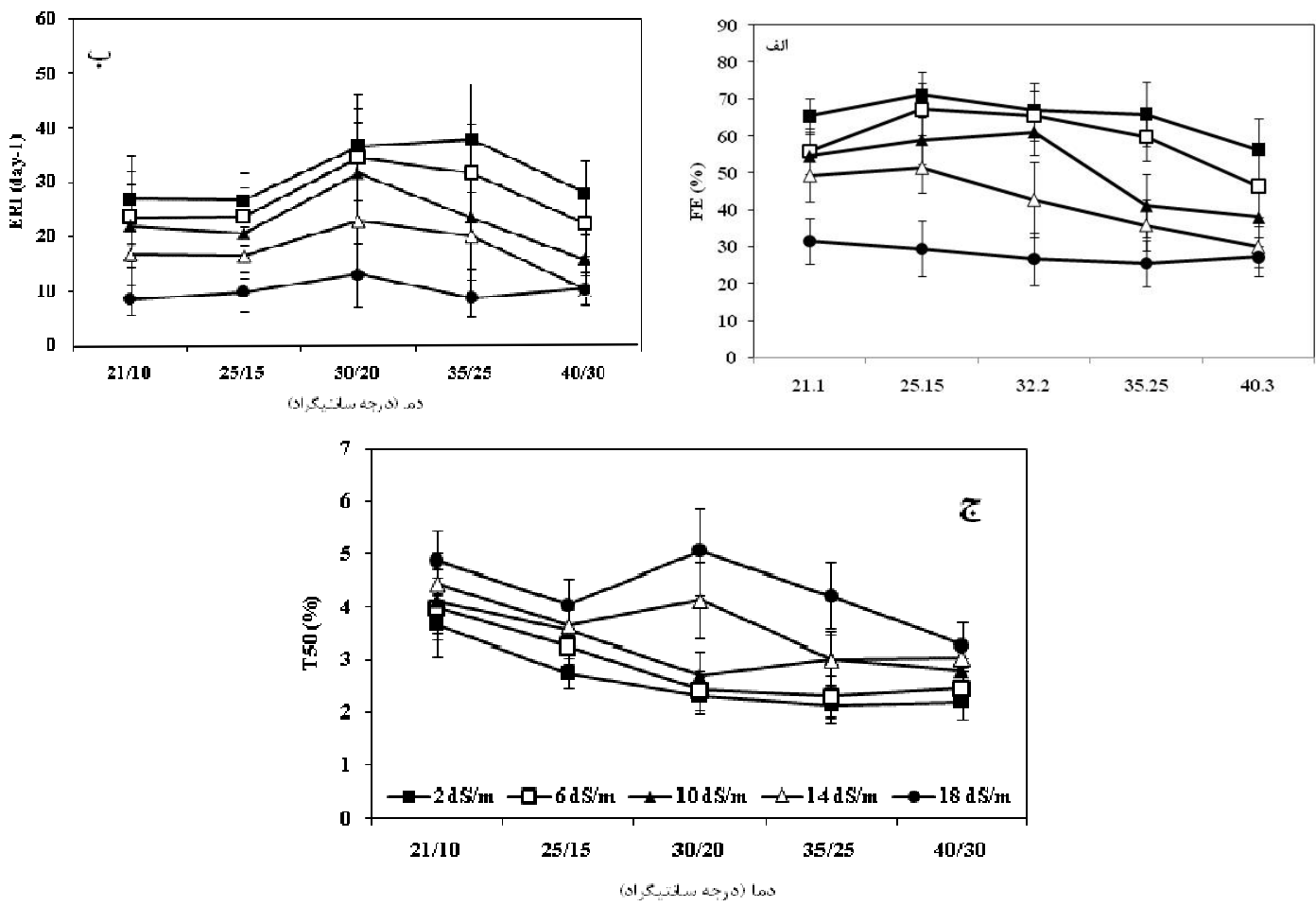

شكل r- برهمكنش دما و شورى الف: بر درصد سبز شدن نهايى (FE)، ب: شاخص سرعت سبز شدن (ERI) و ج: روز تا • هـ سبز شدن (T) (T)

Kochia indica د

جدول بـ - ميزان يارامترهاى موردنياز براى رابطه ركرسيونى لجستيك براى پيشبينى ميزان سبز شدن كوشيا در سطوح مختلف شورى و دما

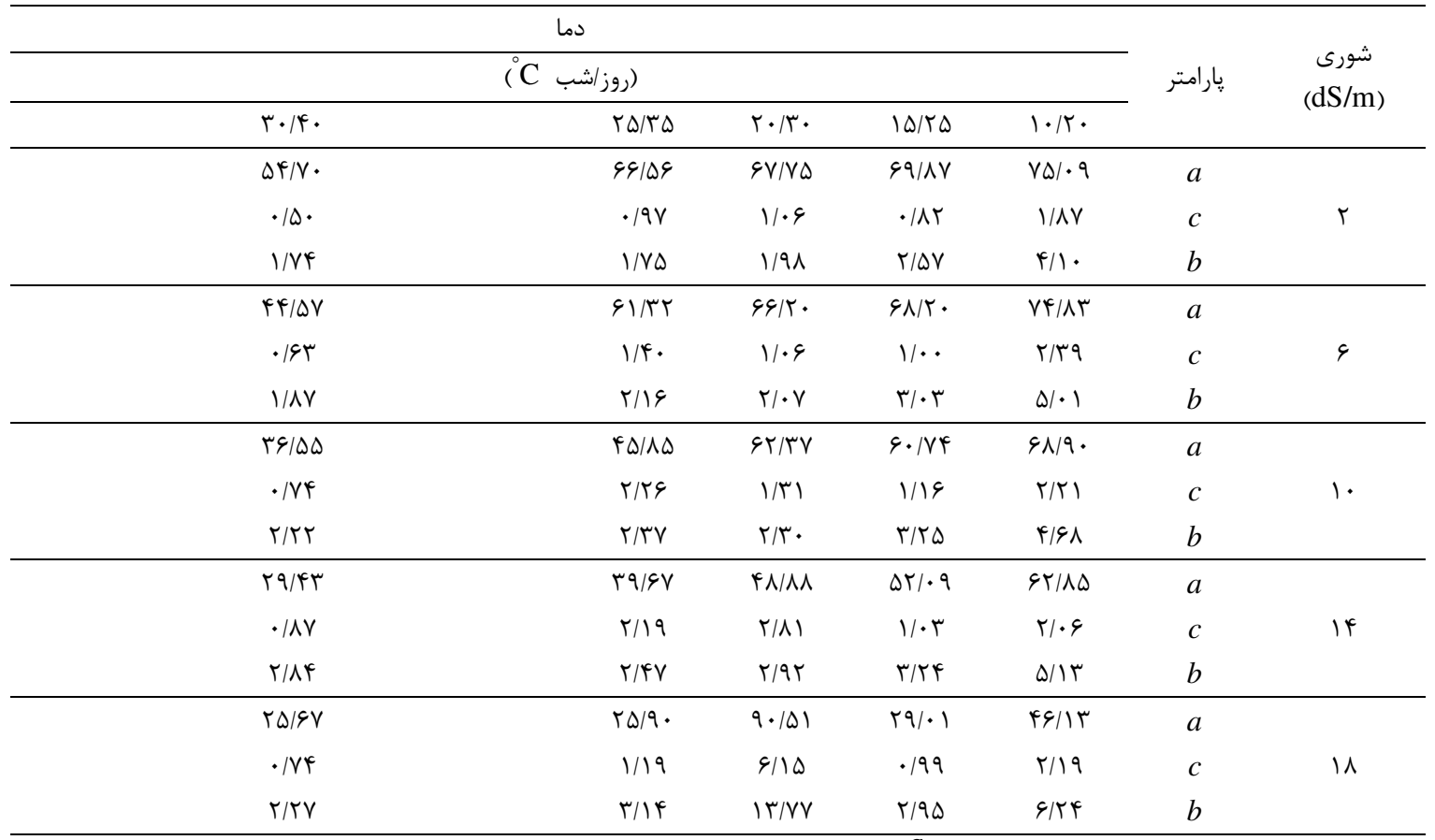

برازش ميزان سبز شدن با استفاده از رابطه

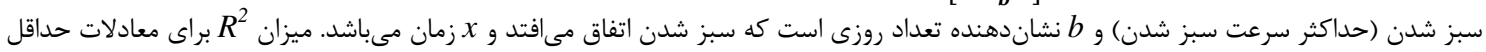


تمام عمقهاى كاشت كاهش يافت، بلطورى كه كمترين درصد سبز در تمام تيمارهاى عمق كاشت مربوط به

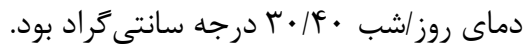
قرار دادن بذر در زير خاك باعث كاهش شديد شاخص سرعت سبز شدن در مقايسه با عمق كاشت

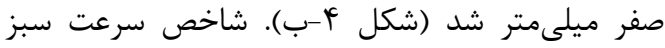
شدن بلطور متوسط از ها هذ بذر در روز در تيمار قرار

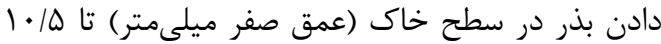
بذر در روز در تيمارهاى قرار دادن بذر در زير سطح

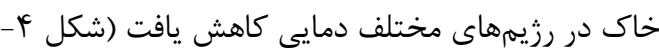

$$
\text { ب) }
$$

در مقايسه با درصد نهايى سبز شدن و شاخص

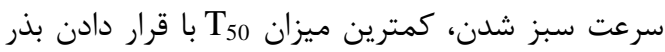
در سطح خاك در تمام عمقهاى كاشت به دست دآ آمد بد

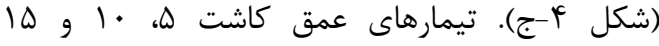

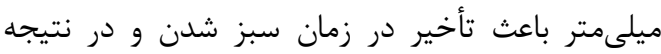
افزايش در ميزان T5 در تمام تيمارهاى دمايى شد. اين بدين معنى است كه در سيستمهاى بدون خاكورزى در مقايسه با سيستمهاى سنتى اين كياه مىتواند موفقتر باشد؛ بنابراين عمليات خاكورزى و به زير خاك كردن آنسائن بذر اين كياه مىتواند به كنترل مؤثر آن در سيستمهاى كشت منجر كردد. تأثير عمق كاشت و دما بر ميزان سبز شدن بذر بسيارى از علفهاى هرز مطالعه شده است (جاكاليس و و

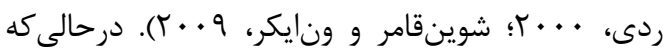
بذر برخى از كونهها تحت تأثير عمق كاشت قرارئ

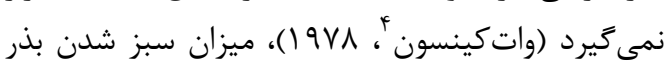

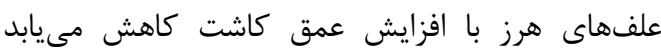

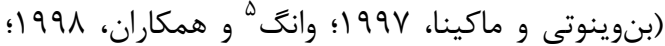

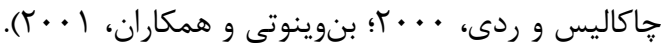
به نظر مىرسد ذخيره كربوهيدرات كم بذرهاى كوجى

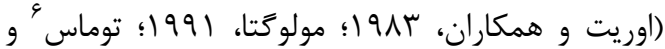

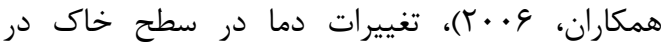
مقايسه با تغييرات كمتر دما در عمقهاى پإيينتر

\footnotetext{
${ }^{4}$ Watkinson

${ }^{5}$ Wang
}

${ }^{6}$ Thomas
جدول f- درصد سبز شدن نهايى (FE)، شاخص سرعت سبز

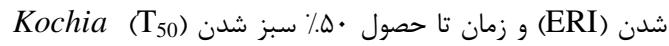
indica

\begin{tabular}{|c|c|c|c|}
\hline $\begin{array}{l}\mathrm{T}_{50} \\
(j و)\end{array}$ & $\begin{array}{c}\text { ERI } \\
\text { (بذر در روز) }\end{array}$ & $\begin{array}{c}\text { FE } \\
(د ر د)\end{array}$ & عمق كاشت \\
\hline 1/1r & $\Delta \Delta / \Delta \Delta$ & $V V / \cdot r$ & . \\
\hline$r / v \wedge$ & $\mid \Delta / g r$ & $\Delta r / q T$ & $\Delta$ \\
\hline$r / 9 V$ & $1 \cdot 19 \Delta$ & $F r / I T$ & 1. \\
\hline$F / F G$ & $\Delta / / \Lambda$ & $|r| /$. & 10 \\
\hline .111 & $1 / 48$ & ו I & LSD \\
\hline
\end{tabular}

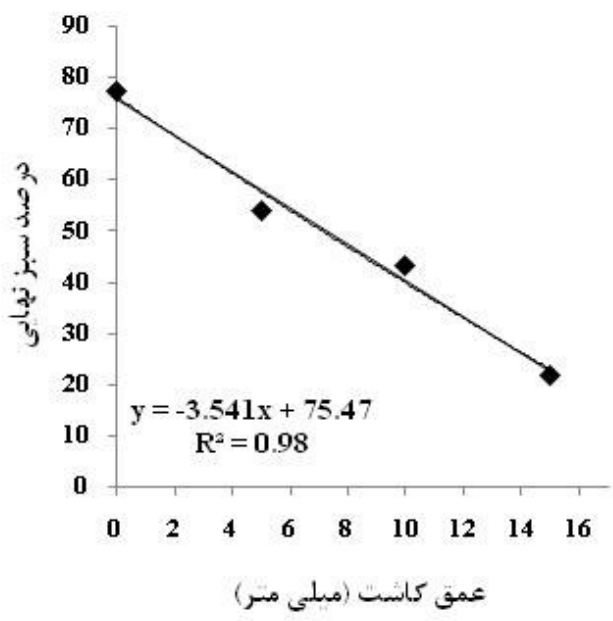

شكل r - كمىسازى واكنش سرعت سبز شدن Kochia indica به عمق كاشت بذر

K. اين نتيجه توسط يروهشخران ديخر روى كونه scoparia

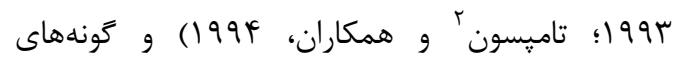
Agriophyllum gassia dasyphylla squarrosum

\section{برهمكنش دما و عمق كاشت}

بيشترين درصد سبز شدن نهايى K. indica در

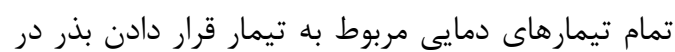
سطح خاك (عمق صفر ميلىمتر) بود (شكل \& أ-الف).

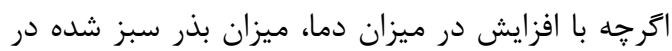

\footnotetext{
${ }^{1}$ Dyer

2 Thompson

${ }^{3}$ Tobe
} 

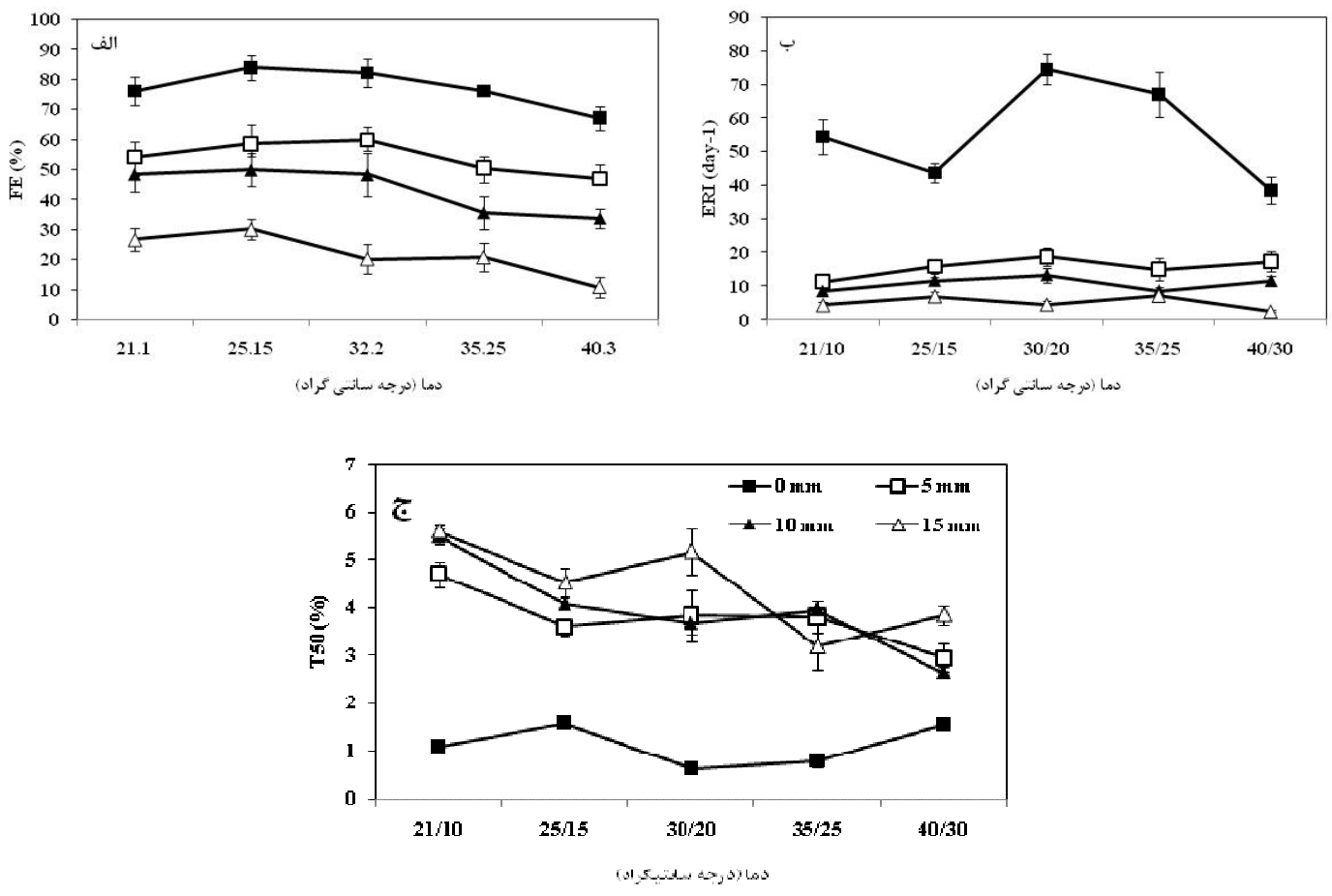

شكل f- برهمكنش دما و عمق كاشت الف: بر درصد سبز شدن نهايى (FE)، ب: شاخص سرعت سبز شدن (ERI) و ج: روز تا •ه. سبز شدن Kochia indica $\left(\mathrm{T}_{50}\right)$

عمق كاشت گزارش كرد كه با افزايش ميزان شورى Bromus tectorum ميزان جوانهزنى علف يشمكى برنى كاهش يافت. با اين حال برخلاف آزمايش حاضر، كمترين ميزان

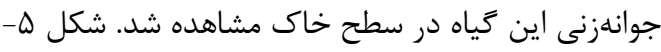
الف همجنين نشان داد كه K. indica در دامنه شورى Y تا ل | دسىزيمنس بر متر قادر به سبز شدن حتى به

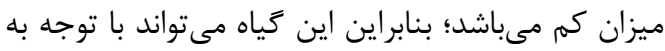
توليد بذر زياد در هر بوته، مناطق وسيعى را در اراضى

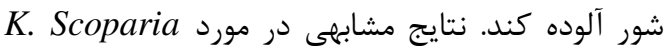

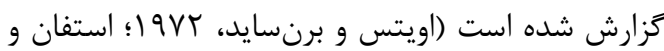
وال، س991؛ خان و همكاران، ا ( •r). در عوض ميزان Th با افزايش ميزان شورى و ميزان عمق كاشت افزايش

$$
\text { يافت (شكل ه-ج). }
$$

بسته به ميزان شورى، ميزان

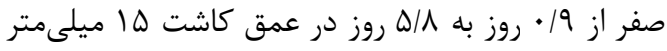

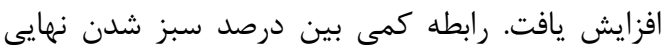

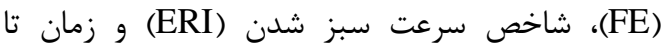

(استيكل و همكاران، † + ·ץ)، مقاومت مكانيكى بيشتر

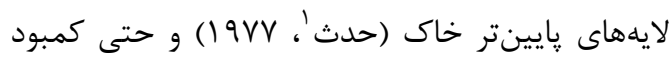
اكسيزن در لايههاى يايينتر خاك (توب و همكاران،

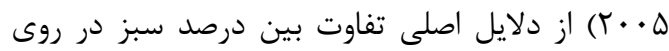
سطح خاى در مقايسه با عمقهاى پايينتر مىباشد. برهمكنش شورى و عمق كاشت برهمكنش شورى و عمق كاشت در درصد سبز شدن نهايى و شاخص سرعت سبز شدن K. indica بهصورت

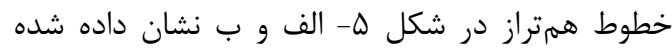

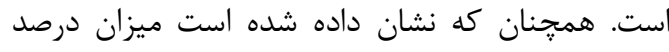
سبز شدن و شاخص سرعت سبز شدن با افزايش شورى و عمق كاشت كاهش يافت.

بيشترين درصد سبز شدن به ميزان 9 ^.٪ با قرار

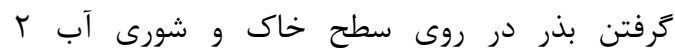
دسىزيمنس بر متر به دست آمد. اسلامى و همكاران

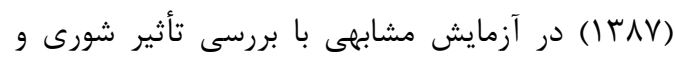

\footnotetext{
${ }^{1}$ Hadas
} 

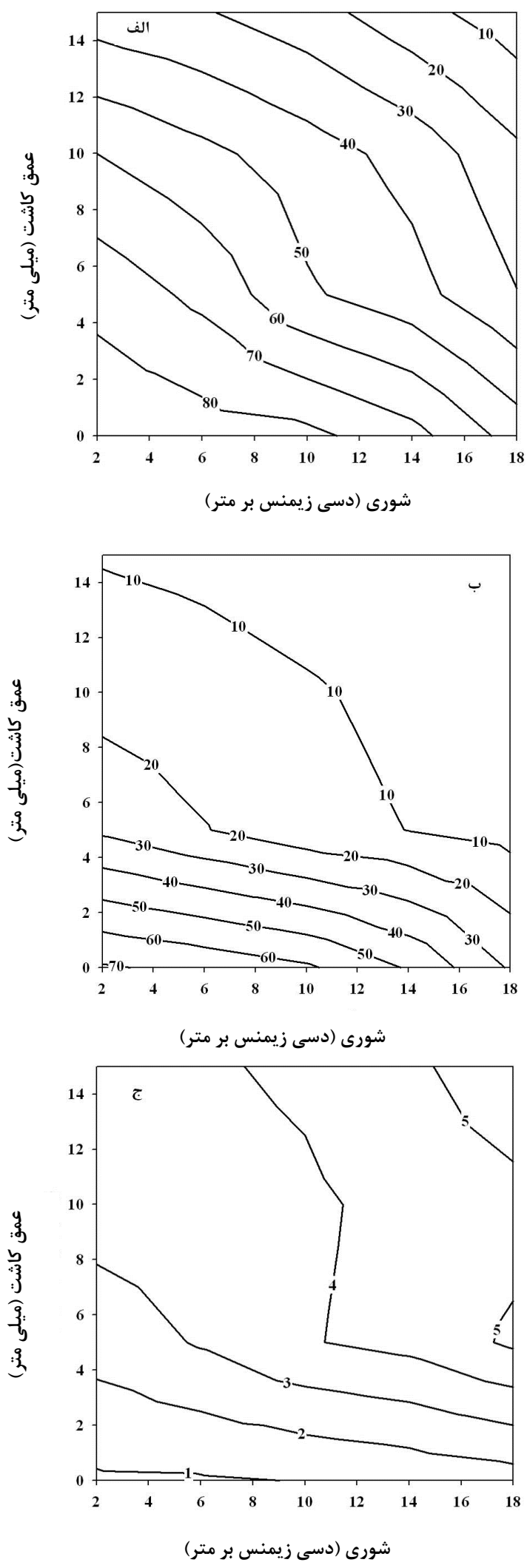

شكل ه- كمىسازى درصد سبز نهايى (الف)، شاخص سرعت سبز شدن (ب) و روز تا • هـ٪ سبز شدن (ج) در Kochia indica با استفاده از

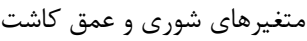


كه گياهان زراعى در شرايط شور با آن مواجه مىباشند

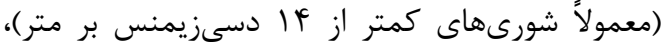
بهويزه زمانى كه در سطح خاك قرار گيرد سبز گردد؛

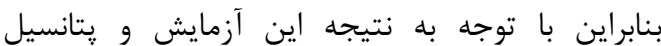
تهاجمى گونههاى كوشيا توصيه مى گردد در صورتى كه هدف از كشت اين گونهها توليد علوفه باشد، كشت آنهائ در اراضى پاييندست حوزهها، جاييكه مناسب كشت إن كياهان زراعى نبوده و بباندازه كافى از سيستمهاى كشت گياهان زراعى فاصله دارد، انجام گيرد. تا از آلوده شدن سيستمهاى زراعى بلهوسيله اين زونهها ممانعت

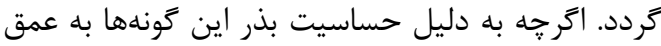
كاشت، مىتوان در سيستمهاى زراعى با دفن نمودن بذر در اعماق پايينتر خاى بلهوسيله سيستمهاى مرسوم خاكورزى، به كنترل مؤثر آنها يرداخت.

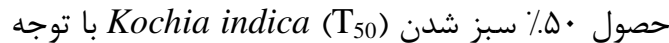
به متغيرهاى شورى (S) و عمق كاشت (D) در شكل ه ه نشان داده شده است.

نتيجهَ نتايج اين مطالعه نشان داد كه Kochia indica در دامنه وسيعى از درجه حرارت كه معمولاً در بهار و و تابستان مىتواند در مناطق مختلفى از كشور اتفاق بيفتد، سبز مى گردد. اين بدين معنى است كه ميزان دما بلهنوان يك فاكتور محدودكننده براى رشد اين گونه محسوب نمى خردد.

همجنين درصد سبز شدن K. indica بيشتر تحت تأثير عمق كاشت قرار گرفت و تأثير تنش شورى بر درن ميزان نهايى بوتههاى سبز شده كمتر بود. به عبارت

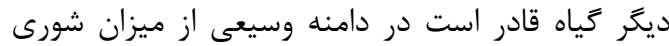

منابع اسلامى، س.و.، افغانى، ف. و محمودى، س. IYNV FV-QV بناكار، م.ح.، رنجبر، غ·ح. و سلطانى، و. اوبا. واكنش فيزيولوزيكى تعدادى از زياهان شورزيست علوفهاى در شرايط شور.

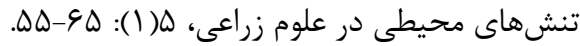
درخشان، ا.، گرزين، م.، قربانيور، ا.، سنجولى، ا. و كامكار، ب. بوسا. تأثير عوامل محيطى بر جوانهزنى بذر و سبز شدن

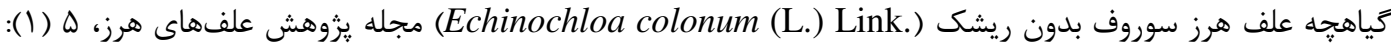

رنجبر، غ.، ويرسته انوشه، ه.، امام، ى.، و حسينزاده، س.ح. rوبا. تأثير تنش شورى بر مراحل مختلف رشد كندم رقم روشن. مجله توليد گياهان زراعى در شرايط تنشهاى محيطى، له( (1): آ-س؟.

سلطانى، ا. و مداح، و. و^^זا. برنامههاى كاربردى ساده براى آموزش و يزوهش در زراعت. انتشارات انجمن بومشناختى دانشگاه شهيد بهشتى. • 1 صفحه.

سلطانى، ا.، سلطانى، ا.، كالشى، س.، قادرىفر، ف. و زينلى، ا. بوسا. كمىسازى سبز شدن بذرهاى كلزاى خودرو و خردل

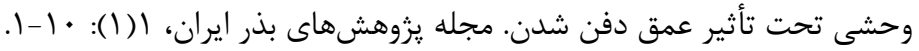

نباتى، ج.، كافى، م.، خانىنزاد، س.، معصومى، ع. و زارع مهرجردى، م. بوس ا. ارزيابى خصوصيات كيفى علوفه ينج توده

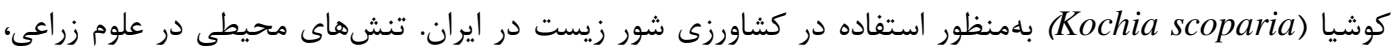

$19 \Delta-\zeta \cdot G:(\zeta) V$

Al-Ahmadi, M., and Kafi, M. 2007. Cardinal temperatures for germination of Kochia scoparia (L.). Journal of Arid Environment, 68(2): 308-314. 
Andrews, M., Scott, W.A., and Mckenzie, B.A. 1991. Nitrate effects on pre-emergence growth and emergence percentage of wheat (Triticum aestivum L.) from different sowing depths. Journal of Experimental Botany, 42(11): 1449-1454.

Benvenuti, S., and Macchia, M. 1997. Germination ecophysiology of bur beggarticks (Bidens tripartita) as affected by light and oxygen. Weed Science, 45(5): 696-700.

Benvenuti, S., Macchia, M., and Miele, S. 2001. Quantitative analysis of emergence of seedlings from buried weed seeds with increasing soil depth. Weed Science, 49(4): 528-535.

Blackshaw, R.E., Brandt, R.N., and Entz, T. 2002. Soil temperature and soil water effects on henbit emergence. Weed Science, 50(4): 494-497.

Boyd, N., and Van Acker, R.C. 2003. The effects of depth and fluctuating soil moisture on the emergence of eight annual and six perennial plant species. Weed Science, 51(5): 725-730.

Chachalis, D., and Reddy, K.N. 2000. Factors affecting Campsis radicans seed germination and seedling emergence. Weed Science, 48(2): 212-216.

Coolbear, P. 1980. Osmotic pre-sowing treatments and nucleic acid accumulation in tomato seeds (Lycopersicon lycopersicum). Seed Science and Technology, 8: 289-303.

Cousens, R., and Moss, S.R. 1990. A model of the effects of cultivation on the vertical distribution of weed seeds within the soil. Weed Research, 30(1): 61-70.

DiTommaso, A. 2004. Germination behavior of common ragweed (Ambrosia artemisiifolia) populations across a range of salinities. Weed Science, 52(6): 1002-1009.

Dyer, W., Chee, P., and Fay, P. 1993. Rapid germination of sulfonylurea-resistant (Kochia scoparia) accessions is associated with elevated seed levels of branched chain amino acids. Weed Science, 41(1): 18-22.

Everitt, J.H., Ala, M.A., and Lee, J.B. 1983. Seed germination characteristics of (Kochia scoparia). Journal of Range Management, 36(5): 662-664.

Evetts, L.L., and Burnside, O.C. 1972. Germination and seedling development of common milkweed and other species. Weed Science, 20: 371-378.

Forcella, F., Wilson, R., Dekker, J., Kremer, R., Cardina, J., Anderson, R., Alm, D., Renner, K., Harvey, R., Clay, S., and Buhler, D. 1997. Weed seed bank emergence across the Corn Belt. Weed Science, 45(1): 67-76.

Friesen, L.F., Beckie, H.J., Warwick, S.I., and Van Acker, R.C. 2009. The biology of Canadian weeds. 138. ochia scoparia (L.) Schrad. Canadian Journal of Plant Science, 89(1): 141-167

Greipsson, S., and Davy, A.J. 1994. Germination of Leymus arenarius and its significance for land reclamation in Iceland. Annals if Botany, 73(4): 393-401.

Grundy, A.C., Mead, A., and Bond, W. 1996. Modeling the effect of weed-seed distribution in the soil profile on seedling emergence. Weed Research, 36(5): 375-384.

Guo, P., Al-Khatib, K. 2003. Temperature effects on germination and growth of redroot pigweed (Amaranthus retroflexus), Palmer amaranth (A. palmeri), and common waterhemp (A. rudis). Weed Science, 51(6): 869-875.

Hadas, A. 1977. Water uptake and germination of leguminous seeds in soils of changing matric and osmotic water potential. Journal of Experimental Botany, 28(105): 977-985.

Kader, M.A. 2005. A comparison of seed germination calculation formulae and the associated interpretation of resulting data. Journal and Proceeding of the Royal Society of New South Wales, 138: 65-75.

Khan, M.A, Gul, B., and Weber, D.J. 2001. Influence of salinity and temperature on the germination of Kochia scoparia. Wetlands Ecology and Management, 9(6): 483-489. 
Kiang, Y.T. 1982. Local differentiation of Anthoxanthum odoratum L. populations on roadsides. American Midland Naturalist, 107(2): 340-350.

Liebman, M., Mohler, C.L., and Staver, C.P. 2001. Ecological management of agricultural weeds. Cambridg University Press. 531p.

Maas, E.V., and Grattan, S.R. 1999. Crop yield as affected by salinity. In Skaggs, R.W., and Van Schilfgaarde, J. (ed.). Agricultural Drainage. Madison, USA. 55-108.

Marlis, H., and Ungar, I.A. 1990. The effect of salinity on seed germination and seedling growth of Echinochloa crusgalli. The Ohio Journal of Science, 90(1): 13-15.

Mickelson, J.A., Bussan, A.J., Davis, E.S., Hulting, A.G., and Dyer, W.E. 2004. Postharvest kochia (Kochia scoparia) management with herbicides in small grains. Weed Technology, 18(2): 426431.

Mohler, C.L., and Galford, A.E. 1997. Weed seedling emergence and seed survival: separating the effects of seed position and soil modification by tillage. Weed Research, 37(3): 147-155.

Mulugeta, D. 1991. Management, inheritance, and gene flow resistance to chlorsulfuron in Kochia scoparia L. (Schrad). (Doctoral dissertation, Montana State University-Bozeman, College of Agriculture). $147 \mathrm{p}$.

Munns, R., and Tester, M. 2008. Mechanisms of salinity tolerance. Annual Review of Plant Biology, 59: 651-681.

Naidoo, G., and Naicker, K. 1992. Seed germination in the coastal halophytes Triglochin bulbosa and Triglochin striata. Aquatic Botany, 42(3): 217-229.

Nussbaum, E., Wiese, A., Crutchfield, D., Chenault, E., and Lavake, D. 1985. The effect of temperature and rainfall on emergence and growth of eight weeds. Weed Science, 33(2): 165170.

Penfield, S. 2008. Temperature perception and signal transduction in plants. Tansley Review of New Phytology, 179(3): 615-628

Radosevich, S.R., Holt, J.S., and Ghersa, C. 1997. Weed ecology: implications for management. John Wiley and Sons Press, New York, USA. 589p

Ranjbar, G.H., Ghadiri, H., and Sepaskhah, A.R. 2014. Effects of irrigation water salinity and Kochia indica density on sorghum and $K$. indica dry matter and chemical composition. Journal of Biological and Environmental Sciences, 8: 115-123.

Schwinghamer, T.D., Van Acker, R.C. 2008. Emergence timing and persistence of kochia (Kochia scoparia). Weed Science, 56(1): 37-41.

Sharma, M.L. 1976. Interaction of water potential and temperature effects on germination of three semi-arid plant species. Agronomy Journal, 68(2): 390-394.

Steckel, L.E., Sprague, C.L., Stoller, E.W., and Wax, L.M. 2004. Temperature effects on germination of nine Amaranthus species. Weed Science, 52(2): 217-221.

Steppuhn, H., and Wall, K. 1993. Kochia scoparia emergence from saline soil under various water regimes. Journal of Range Management, 46(6): 533-538.

Tadmor, N.H., Cohen, Y., and Harpaz, Y. 1969. Interactive effects of temperature and osmotic potential on the germination of range plants. Crop Science, 9(6): 771-774.

Thomas, W.E., Burke, I.C., Spears, J.F., and Wilcut, J.W. 2006. Influence of environmental factors on slender amaranth (Amaranthus viridis) germination. Weed Science, 54(2): 316-320.

Thompson, C., Thill, D., and Shafi, B. 1994. Germination characteristics of sulfonylurea-resistant and -susceptible kochia (Kochia scoparia). Weed Science, 42(1): 50-56. 
Thornley, J.H.N., and Johnson, I.R. 1990. Plant and crop modeling: a mathematical approach to plant and crop physiology. Oxford Press. New York, USA. 669p

Tobe, K., Zhang, L., and Omasa, K.I. 2005. Seed germination and seedling emergence of three annuals growing on Desert Sand Dunes in China. Annals of Botany, 95(4): 649-659.

Wang, Z.L., Wang, G., and Liu, X.M. 1998. Germination strategy of the temperate sandy desert annual chenopod Agriophyllum squarrosum. Journal of Arid Environments, 40(1): 69-76.

Watkinson, A.R. 1978. The demography of a sand dune annual: Vulpia fasciculata. II. The dynamics of seed populations. Journal of Ecology, 66(1): 35-44.

Yenish, J.P., Fry, T.A., Durgan, B.R., and Wyse, D.L. 1996. Tillage effects on seed distribution and common milkweed (Asclepias syriaca) establishment. Weed Science, 44(4): 815-820.

Zia, S., and Khan, M.A. 2004. Effect of light, salinity, and temperature on seed germination of Limonium stocksii. Canadian Journal of Botany, 82(2): 151-157. 


\title{
Quantification of Seedling Emergence of Kochia (Kochia indica) Affected by Temperature, Salinity and Seeding Depth
}

\author{
Gholamhassan Ranjbar ${ }^{1,}$, Hossein Ghadiri ${ }^{2}$ \\ ${ }^{1}$ Assistant Professor, National Salinity Research Center, Agricultural Research, Education and \\ Extension Organization (AREEO), Yazd, Iran \\ ${ }^{2}$ Department of Crop Production and Plant Breeding, College of Agriculture, Shiraz University, \\ Shiraz, Iran \\ *Corresponding author, E-mail address: ranjbar@areeo.ac.ir
}

(Received: 21.09.2015 ; Accepted: 26.06.2016)

\begin{abstract}
A controlled experiment was run to quantify emergence of Kochia indica under different temperature, salinity and seeding depth levels at Yazd National Salinity Research Center in 2013. Treatments were five day/night temperature regimes: 20/10, 25/15, 30/20, 35/25 and 40/30 ${ }^{\circ} \mathrm{C}$, five salinity levels: $2,6,10,14$ and $18 \mathrm{dS} \mathrm{m}^{-1}$, and seeding depth on the surface $(0 \mathrm{~mm}), 5,10$ and 15 $\mathrm{mm}$. Final emergence percentage, emergence rate index and elapsed time (days) to reach $50 \%$ of the maximum emergence were measured. The results showed that the highest and lowest final emergence percentages were observed at $25 / 15^{\circ} \mathrm{C}$ and $40 / 30^{\circ} \mathrm{C}$ day/night, respectively. Final emergence percentages at salinity levels of $6,10,14$ and $18 \mathrm{dS} \mathrm{m}^{-1}$ were, respectively, 9, 22, 36 and $57 \%$ lower than $2 \mathrm{dS} \mathrm{m}^{-1}$. Final emergence percentages for 5, 10 and $15 \mathrm{~mm}$ seeding depths were, respectively, 30, 44 and $72 \%$ lower, as compared with the placement of seeds on the soil surface. Regression analysis showed that final emergence percentage linearly decreased with increase in salinity and seeding depth levels. However, elapsed time (days) to reach $50 \%$ of the maximum emergence $\left(\mathrm{T}_{50}\right)$, increased as salinity and seeding depth increased, so that the highest $\mathrm{T}_{50}$ was obtained for $18 \mathrm{dS} \mathrm{m}^{-1}$ and seeding depth of $15 \mathrm{~mm}$. Increase in salinity and seeding depth was associated with a significant decrease in emergence rate index. In addition, using logistic regression equation, emergence rate of $K$. indica was quantified on each day after sowing for each temperature-salinity combination to predict the distribution range of the plant in these situations.
\end{abstract}

Keywords: Linear regression, Emergence rate index, Weed, Seeding depth, Logistic equation 